(RESEARCH ARTICLE)

\title{
Relative importance of the bacteria Brucella, Salmonella, Staphylococcus and other indicator bacteria in some mountain farm waters in West-Cameroon (Central Africa) and the potential role of some environmental factors
}

Pierrette Ngo Bahebeck ${ }^{12}$, Mireille Ebiane Nougang 3, Paul Alain Nana 4, Claire Stéphane Metsopkeng 1, Antoine Tamsa Arfao ${ }^{1}$, Olive Vivien Noah Ewoti ${ }^{1}$, Luciane Marlyse Moungang ${ }^{1}$, Stephen Lacmata Tamekou 5 , Henri Bayemi Pougue ${ }^{2}$, Fanny Perrière ${ }^{6}$, Télesphore Sime-Ngando ${ }^{6}$ And Moïse Nola ${ }^{*}$

\footnotetext{
${ }^{1}$ Laboratory of Hydrobiology and Environment, Faculty of Science, University of Yaoundé I, P.O. BOX 812, Yaoundé, Cameroon.

2 Institute of Agricultural Research for Development (IRAD), Yaoundé, P.O. BOX 2067 Yaoundé, Cameroon.

${ }^{3}$ Zoology Laboratory, Faculty of Sciences, University of Maroua, P.O.BOX 814 Maroua, Cameroon.

4 Department of Oceanography and Limnology, Institute of Fisheries and Aquatic Sciences, University of Douala, P.O.BOX 7236, Douala, Cameroon.

${ }^{5}$ Research Unit of Microbiology and Antimicrobial Substances (RUMAS), Faculty of Sciences, University of Dschang, P.O. BOX 67, Dschang, Cameroon.

${ }^{6}$ Laboratoire "Microorganismes : Génome et Environnement (LMGE) », Université Clermont Auvergne, Aubière cedex, France.
}

Publication history: Received on 15 October 2020; revised on 27 October 2020; accepted on 30 October 2020

Article DOI: https://doi.org/10.30574/wjarr.2020.8.2.0396

\begin{abstract}
A bacteriological and physicochemical study was conducted in the waters of farms in mountainous regions of Cameroon. The different water samples were collected during two campaigns in December 2018 and February 2019. Ten stations representing the drinking water supply points in our study area were identified. The results showed that these waters contained both pathogenic and commensal fecal bacteria. The highest abundances reached $10 \times 10^{3} \mathrm{CFU} / 100 \mathrm{~mL}$ for Salmonella sp., $72 \times 10^{3} \mathrm{CFU} / 100 \mathrm{~mL}$ for Staphylococcus aureus, $102 \times 10^{3} \mathrm{CFU} / 100 \mathrm{~mL}$ for Brucella suis and $40 \times 10^{3}$ $\mathrm{CFU} / 100 \mathrm{~mL}$ for Brucella abortus. These abundances were subject to space-time fluctuations. Water contamination by tweezers was not general and was present only in surface waters (rivers and ponds). The water in the ponds, rivers and wells analyzed were all basic, with low mineralization on average. The dissolved oxygen ranged from 37.5 to $70.6 \%$, nitrate from 3.7 to $19.8 \mathrm{mg} / \mathrm{L}$ and iron from 0.01 to $3.5 \mathrm{mg} / \mathrm{L}$. Most of the physicochemical parameters were relatively stable during the two campaigns. The degree of correlation between the physicochemical parameters and the abundance dynamics of the isolated bacteria was heterogeneous. This was clearly more pronounced with Salmonella sp. and Brucella suis. This would be due to the fraction of metabolically active cells present when the bacteria are exposed to unfavorable conditions. Correlations with the abiotic factors were less marked with Staphylococcus aureus and Brucella abortus; this would be due to their tolerance to environmental stresses.
\end{abstract}

Keywords: Brucella abortus; Brucella suis; farm water; physicochemical parameters; Salmonella sp.; Staphylococcus aureus

\section{Introduction}

Water is of paramount importance as a vital nutrient involved in many essential physiological functions such as digestion, absorption, thermoregulation and waste disposal [1]. Its availability and quality are key parameters in the

${ }^{*}$ Corresponding author: Moïse Nola ; Email: moise.nola@yahoo.com

Laboratory of Hydrobiology and Environment, Faculty of Sciences, University of Yaoundé I, P.O. BOX 812, Yaoundé, Cameroon.

Copyright (c) 2020 Author(s) retain the copyrig0ht of this article. This article is published under the terms of the Creative Commons Attribution Liscense 4.0. 
health and productivity of livestock [2]. The physicochemical properties of water such as temperature, $\mathrm{pH}$, dissolved oxygen, organic matter and the concentration of available nutrients can affect the growth rate of the microorganism's present [3].

Bacteria are generally the most abundant microorganisms in water. Some of the most commonly encountered pathogenic bacteria are salmonella and staphylococci [4,5]. Indeed, many strains of Salmonella have been incriminated as an etiological agent of childhood diarrhoea in humans, diarrhoea, urinary tract infections, gastroenteric infections, meningitis and septicaemia in animals [6]. Salmonella is of considerable importance in the veterinary and medical fields. This is due to the economic losses due to production losses, seizures and costs incurred by prevention methods and their monitoring, as well as the high incidence of collective food-borne infections, in a context where a high level of food safety is demanded by the consumer [7]. The survival of Salmonella in water would be linked to the availability of nutrients and competition with native bacteria [5].

Staphylococcus aureus is a major public health issue. It is responsible for a wide variety of infections. Several antibioticresistant strains have been encountered in certain production animals such as swine and poultry. They constitute a risk of transmission to humans via the food chain. They can form biofilm which increases their tolerance to environmental stresses and are very virulent due to its many virulence factors [4].

Brucella are facultative intracellular pathogens, parasites of the reticulohistiocytic system [8]. They are pathogenic to many mammalian species, both domestic and wild. Some Brucella species are pathogenic to humans: Brucella melitensis (transmitted by goats and sheep), Brucella abortus (cattle), Brucella suis (pigs) and Brucella canis (dogs) [9,10,11]. Infected animals spread Brucella in the environment, through their "waters" during abortion or calving, their placenta, their vaginal secretions in infected females, or through milk. These bacteria are resistant for several months (on average 3 months) under natural storage conditions (milk, cheese, feces, soil, water, stable walls or sheepfolds), which may have practical consequences for the contamination of humans [12,13].

In Cameroon, data on the prevalence of brucellosis are fragmentary. Prevalence's ranging from 3\% to $31 \%$ in cattle at the individual level, from $16.2 \%$ to $35 \%$ in herds in the Northern, Adamaoua and Western regions and from $0.28 \%$ to $12.5 \%$ in humans in the Adamaoua region have been reported [14,15]. However, there are no data on the isolation of Brucella sp. bacteria from aquatic environments in Cameroon. It is therefore difficult to determine precisely the nature and extent of the health risks that could be incurred by those animals which consume these waters. Few studies have been carried out on the characterization of farm water in the equatorial zone in Cameroon. The aim of this study is to characterize the bacteria Brucella sp., Salmonella sp. and Staphylococcus aureus in farm water in mountainous regions of Cameroon, and to evaluate the potential role of abiotic factors.

\section{Material and methods}

\subsection{Study area}

The study was conducted in Nde Division located in a mountainous region of Cameroon. It is located between $5^{\circ} 12^{\prime}$ North latitude and $10^{\prime} 23^{\circ}$ East longitude. The Division is divided into 4 district areas Bangangte, Bassamba, Bazou and Tonga (Figure 1). The Nde Division has a total surface area of $17,300 \mathrm{~km}^{2}$ and is home to more than $1,728,953$ inhabitants, with an average density of 100 inhabitants $/ \mathrm{km}^{2}$ [16].

This area is characterized by the temperate sudano-guinean climate which is influenced by the western mountain range with two seasons: a rainy season that extends from mid-March to mid-November and a dry season that extends from mid-November to mid-March. Temperatures range between 14 and $28{ }^{\circ} \mathrm{C}$ with a strong daily variation. The relief varied over its entire extent. It includes plains, plateaus, riverine mountains, hills, valleys, as well as floodplains and swamps suitable for rice cultivation. The soils are fertile and suitable for perennial and food crops. The nature of the soils varies according to the relief. They are ferralitic and yellow-brownish on the plateaus and hills, sandy, clayey, ferralitic and lateritic brown on the plains, clayey, calcareous and poorly developed on the slopes and hillsides, and hydromorphic in the valleys [17]. A subsoil whose mining potential would be established by in-depth geological studies contains bauxite, tin oxide, copper, pozzolan and thermal mineral waters. The hydrography of the department is characterized by the existence of numerous rivers, ponds and pools. There is also an abundant and varied flora and vegetation with natural forests rich in game and species and vast expanses of shrubby savannah. Soil fertility reduces the use of chemical fertilizers in the Division [17]. 


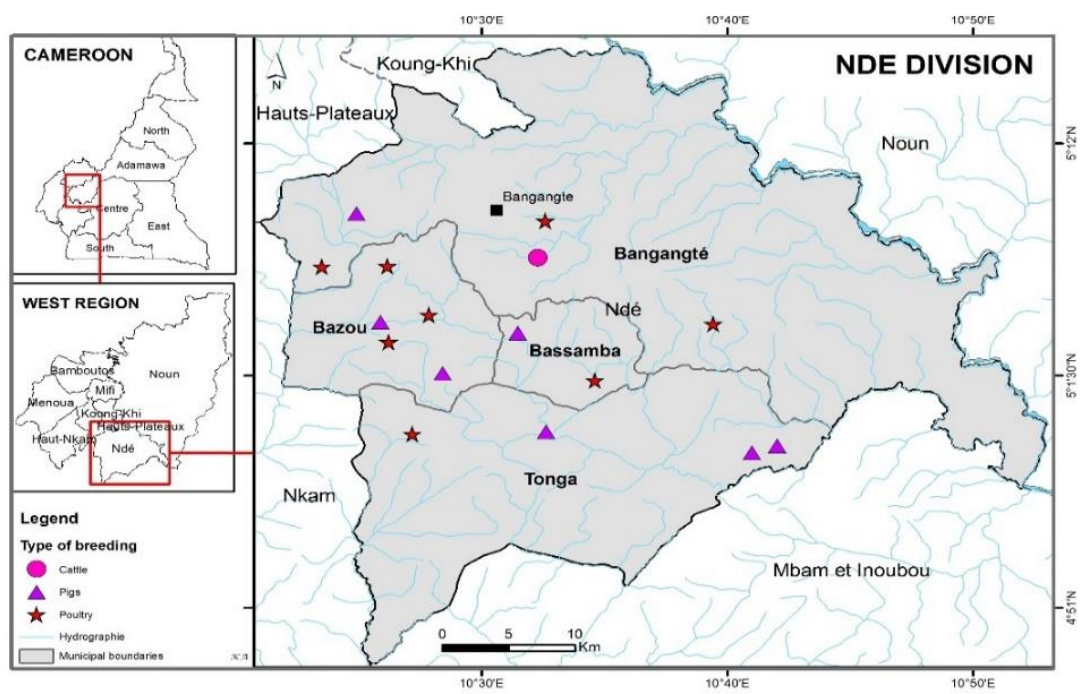

Figure 1 Map of the geographical location of the study area

\subsection{Sampling}

Two water sampling campaigns have been conducted: one during December 2018 and the other during February 2019. To evaluate the bacteriological and physicochemical characteristics of the water of the farms in the Division, 16 farms were approached where the drinking water came from 10 water sources ( $\left.\mathrm{P}_{\mathrm{w}} 1, \mathrm{P}_{\mathrm{w}} 2, \mathrm{R} 1, \mathrm{R} 2, \mathrm{R} 3, \mathrm{R} 4, \mathrm{~W} 1, \mathrm{~W} 2, \mathrm{~W} 3, \mathrm{~W} 4\right)$ (Table 1). The main criteria for selecting farms were the availability of at least 10 animals, their geographical distribution and their water source. These water stations were chosen because of their interest for the population: they are the main sources that supply the farms in these communes (Table 1).

Table 1 Some characteristics of sampling sites

\begin{tabular}{|l|l|l|}
\hline Farms & Water supply sources & Animals \\
\hline F1 & Pond 1 (Pw1) & Pigs \\
\hline F2 & Pond 2 (Pw2) & Pigs \\
\hline F3 & Pond 2 (Pw2) & Pigs \\
\hline F4 & River 1 (R1) & Pigs \\
\hline F5 & River 1 (R1) & Pigs \\
\hline F6 & River 1(R1) & Pigs \\
\hline F7 & river drained to a water tower equipped with surface hand pumps (R2) & Pigs \\
\hline F8 & River drained to a water tower equipped with surface hand pumps (R2) & Poultry \\
\hline F9 & River 3 (R3) & Poultry \\
\hline F10 & River 3 (R3) & Poultry \\
\hline F11 & River (R3) & Poultry \\
\hline F12 & River 4 (R4) & Cattle \\
\hline F13 & Well 1 (W1) & Poultry \\
\hline F14 & Well 2 (W2) & Poultry \\
\hline F15 & Well 3 (W3) & Poultry \\
\hline F16 & Well 4 (W4) & Poultry \\
\hline
\end{tabular}

Random samplings have been carried out in the water stations that were dispersed in the different boroughs of our study area. Two water samples were taken from each station. The water samples for bacteriological analysis were taken 
in $500 \mathrm{~mL}$ dry sterile glass vials. These vials were filled 3/4 full of water to allow homogenization prior to seeding. Water samples for physicochemical analysis were collected in $1000 \mathrm{~mL}$ polyethylene bottles which were thoroughly washed, rinsed and dried. At each station, these bottles were first rinsed in the field with the water to be analyzed, then filled to the brim and capped to limit outgassing [18]. All samples were then transported to the laboratory in a refrigerated chamber for analysis.

\subsection{Bacteriological analyses}

The germs sought were isolated on solid culture media by surface spreading techniques. $100 \mu \mathrm{L}$ of the sample were taken with a micropipette and spread on agar cast in a Petri dish around the sterility diameter defined by the flame of the Bunsen burner [19].

The identification of the different species was carried out according to the usual biochemical criteria [20]. Mesophilic aerobic heterotrophic bacteria (MAB), total coliforms (TC), fecal coliforms (FC), fecal streptococci (FS) (Enterococcus feacalis (E. feacalis)), Staphylococcus aureus (S. aureus), Salmonella sp., Brucella suis and Brucella abortus were isolated. The total aerobic mesophilic flora was isolated on Plate Count Agar (PCA) medium by the surface spreading technique [21]. Staphylococci, FS, salmonella, TC and FC were isolated on Chapman, Bile Esculin Azide (BEA), Wilson Blair and Endo culture media, respectively [21]. The tweezers were isolated and cultured on Brucella agar made selective by addition of cycloheximide, bacitracin, polymyxin B, nalidixic acid, nystatin, vancomycin (Brucella supplement) in an atmosphere containing 5 to $10 \% \mathrm{CO}_{2}$ for 2 days of incubation [22]. All visible suspect Brucella sp. colonies were subcultured, typed and identified using standard microbiological procedures [8]. With the exception of the fecal coliforms (FC) which were isolated at $44^{\circ} \mathrm{C}$, the other bacteria were isolated at $37^{\circ} \mathrm{C}$.

\subsubsection{Identification of the Brucella species}

Brucella species isolated were biotyped according to their morphology (translucent, round, even-edged colonies 2-3 $\mathrm{mm}$ in diameter and smooth colonies 1-2 $\mathrm{mm}$ ) and other characteristics such as oxidase, urease and catalase reactions, hydrogen sulfide $\left(\mathrm{H}_{2} \mathrm{~S}\right)$ production, growth in the absence of carbon dioxide $\left(\mathrm{CO}_{2}\right)$ and growth in the presence of the basic dyes fuchsin and thionine [22] (Table 2).

Table 2 Differentiation of Brucella species

\begin{tabular}{|l|c|c|c|c|}
\hline \multirow{2}{*}{$\begin{array}{l}\text { Bacterial } \\
\text { Species }\end{array}$} & \multicolumn{4}{|c|}{ Cells chemical reaction } \\
\cline { 2 - 5 } & CO2 requirement & H2S Training & Thionine & Basic fuchsin \\
\cline { 3 - 5 } & & & $1: 600$ & $1: 200$ \\
\hline B. abortus & + & + & - & + \\
\hline B. suis & - & + & + & - \\
\hline
\end{tabular}

\subsection{Physicochemical analysis}

Physicochemical analyses were performed according to the techniques recommended by Rodier and APHA [19, 23]. The parameters considered were potential hydrogen $(\mathrm{pH})$, temperature, color, suspended solids (SS), turbidity, dissolved oxygen (dissolved $\mathrm{O}_{2}$ ), nitrates and iron. The water temperature and $\mathrm{pH}$ were measured in-situ using a Wagtech portable multi-parameter (waterproof) meter. The water color, SS and turbidity were evaluated by spectrophotometry and the results were expressed in Platinum Cobalt Units (Pt.Co), Milligrams per liter (mg/L) and Formazin Turbidity Unit (FTU). The dissolved $\mathrm{O}_{2}$ content of the water was determined in the field using a Hanna oximeter, model HI 9146, and the result was expressed in percent saturation (\%). The concentrations of nitrates and iron were evaluated using a spectrophotometry were expressed in $\mathrm{mg} / \mathrm{L}$.

\subsection{Data analysis}

The SPSS version 16.0 software was used for statistical analysis after encoding the data in Excel. Principal Component Analysis was used to investigate possible relationships and correlations between the parameters analyzed. 


\section{Results and discussion}

\subsection{Microbiological parameters}

The concentration of $\mathrm{HAB}$ ranged from $85 \times 10^{3}$ to $21920 \times 10^{3} \mathrm{CFU} / 100 \mathrm{~mL}$. The averages for the first and the second campaign were $4305 \times 10^{3}$ and $4597 \times 10^{3} \mathrm{CFU} / 100 \mathrm{~mL}$ respectively. The highest abundance was recorded at the R4 level and the lowest was at the station W1 (Figure 2A).
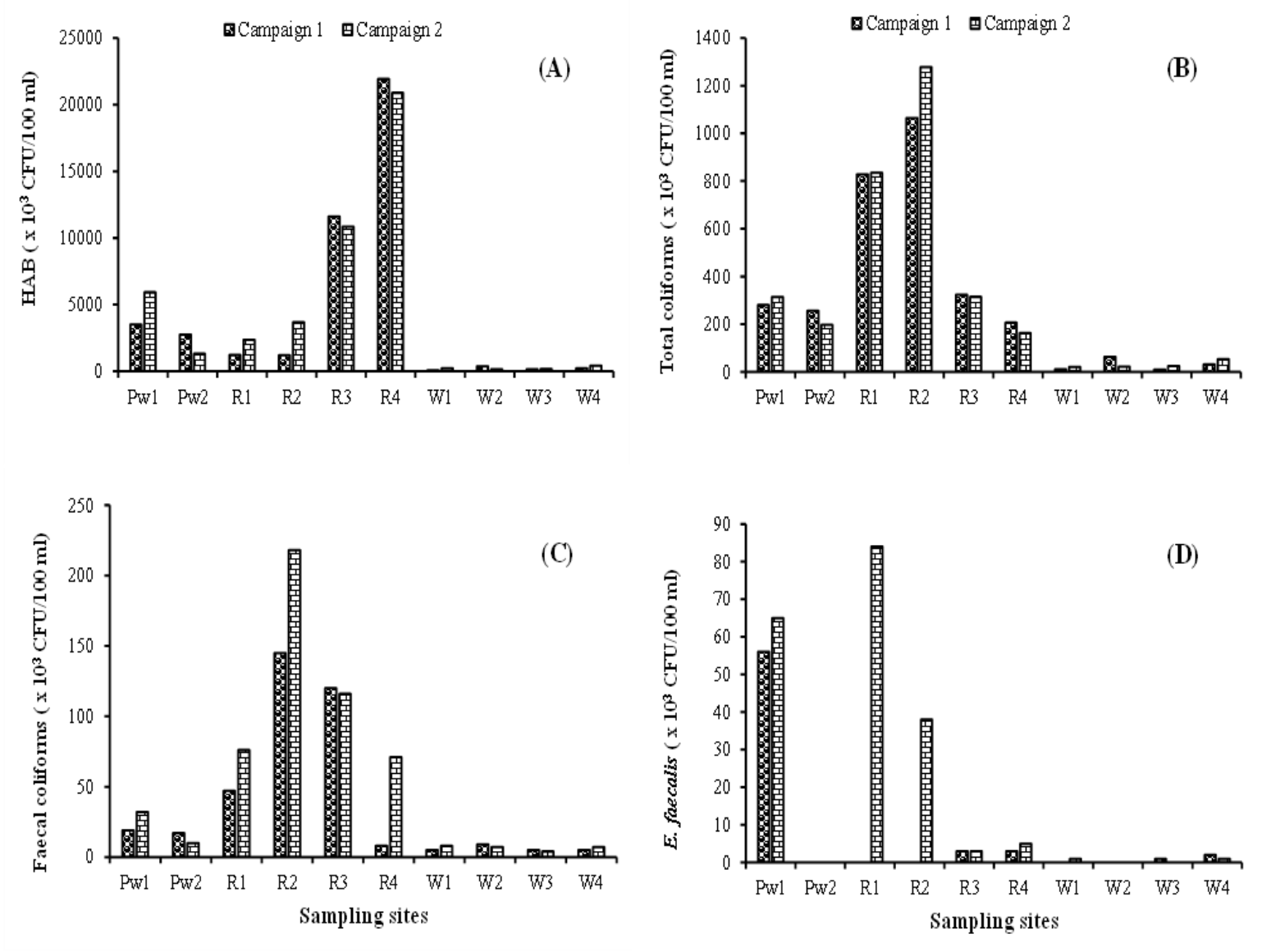

Figure 2 Variation in HAB (A), total coliforms (B), fecal coliforms (C) and Enterococcus faecalis (E. faecalis) at the stations studied during the two campaigns (campaign 1 and campaign 2).

The TC abundance ranged from $10 \times 10^{3}$ to $1278 \times 10^{3} \mathrm{CFU} / 100 \mathrm{~mL}$. The averages for the two periods were $338 \mathrm{x} 10^{3}$ and $352 \times 10^{3} \mathrm{CFU} / 100 \mathrm{~mL}$ respectively. The highest abundance was recorded at $\mathrm{R} 2$ and the lowest was at W3 (Figure 2B).

The FC were of about $47 \times 10^{3} \mathrm{CFU} / 100 \mathrm{~mL}$. The maximum abundance was recorded at $\mathrm{R} 2\left(218 \times 10^{3} \mathrm{CFU} / 100 \mathrm{~mL}\right)$ and the minimum was at station $\mathrm{W} 4\left(4 \times 10^{3} \mathrm{CFU} / 100 \mathrm{~mL}\right)$ (Figure 2C). The highest cells abundance could be linked to the presence of a source of microbial pollution due to the accumulation of fecal matter (animal and human excreta) in the water. Belghiti et al [24] also found FC in wells drinking livestock in the Meknes area in Morocco. TC and FC are considered among the most common and frequently used indicators of fecal water contamination in health risk assessment. These indicators are considered "pathogenic indicators" because of the increased risk of gastrointestinal and associated respiratory diseases [7].

In addition, the water for the farms in this Division comes mainly from surface water. Indeed, in mountainous areas, streams and other surface water sources are the most used [13]. These waters are vulnerable to microbiological and chemical pollution due to discharges related to human activities and runoff [25].

Abundance of fecal streptococci (FS) reached $84 \times 10^{3} \mathrm{CFU} / 100 \mathrm{~mL}$. Their averages varied from $6.5 \times 10^{3}$ to $19.7 \times 10^{3}$ $\mathrm{CFU} / 100 \mathrm{~mL}$ respectively for campaign 1 and 2, with a maximum value recorded at station R1 (Figure 2D). 
The FS, TC and FC were exclusively from the intestines of warm-blooded animals, including humans, and their presence in water may be an indication of fecal contamination and the presence of other dangerous pathogenic microorganisms $[26,27]$.

Testing for FS is a confirmatory parameter for the fecal nature of pollution. Thus, if TC organisms are found in a water sample, the identification of FS will provide important confirmation of fecal pollution [28]. The quantification of the fecal contamination flora has allowed us to follow the evolution of the TC/FS ratio at the level of the stations. Most of the ratios found remain above 4 ; this indicates pollution of human origin.

For Salmonella, the average cells abundance in the studied sites was of the order of $2.4 \times 10^{3}$ and $2.2 \times 10^{3} \mathrm{CFU} / 100 \mathrm{~mL}$ for campaign 1 and 2 respectively, with a maximum value recorded at station R1 (10x103 CFU/100mL) (Figure 3E). According to Jajere [29], at the bacteriological level, it is the risk of salmonellosis that represents the first danger in a farm. Indeed, salmonellosis is of considerable importance in the veterinary and medical field. This is due to the economic losses due to reproductive failures and the costs of prevention methods and their follow-up, as well as the high incidence of food poisoning in the consumer [7].

For all the samples analyzed, the Staphylococcus aureus abundance reached $72 \times 10^{3} \mathrm{CFU} / 100 \mathrm{~mL}$. Only station R4 was free over the two campaigns, the averages of the two campaigns were respectively $11.1 \times 10^{3}$ and $10.8 \times 10^{3} \mathrm{CFU} / 100 \mathrm{~mL}$ (Figure 3F). S. aureus is responsible for many clinical forms, sometimes extremely severe (staphylococcal toxic shock, necrotizing pneumonia, etc.). The severity of $S$. aureus infections is linked on the one hand to host susceptibility, and on the other hand to the finely regulated expression of virulence factors [30]. Several antibiotic-resistant strains have been found in animals. Close human-animal contact and the use of antibiotics in animals seem to be the most likely causes of the emergence of these strains [4].

The abundance of Brucella suis and B. abortus reached respectively $102 \times 10^{3} \mathrm{CFU} / 100 \mathrm{~mL}$ and $40 \times 10^{3} \mathrm{CFU} / 100 \mathrm{~mL}$. The highest abundances were recorded at the R3 level for both species. Only wells (W1, W2, W3, W4) were free of Brucella suis and B. abortus during the both campaigns (Figure $3 \mathrm{G}$ and $3 \mathrm{H}$ ).
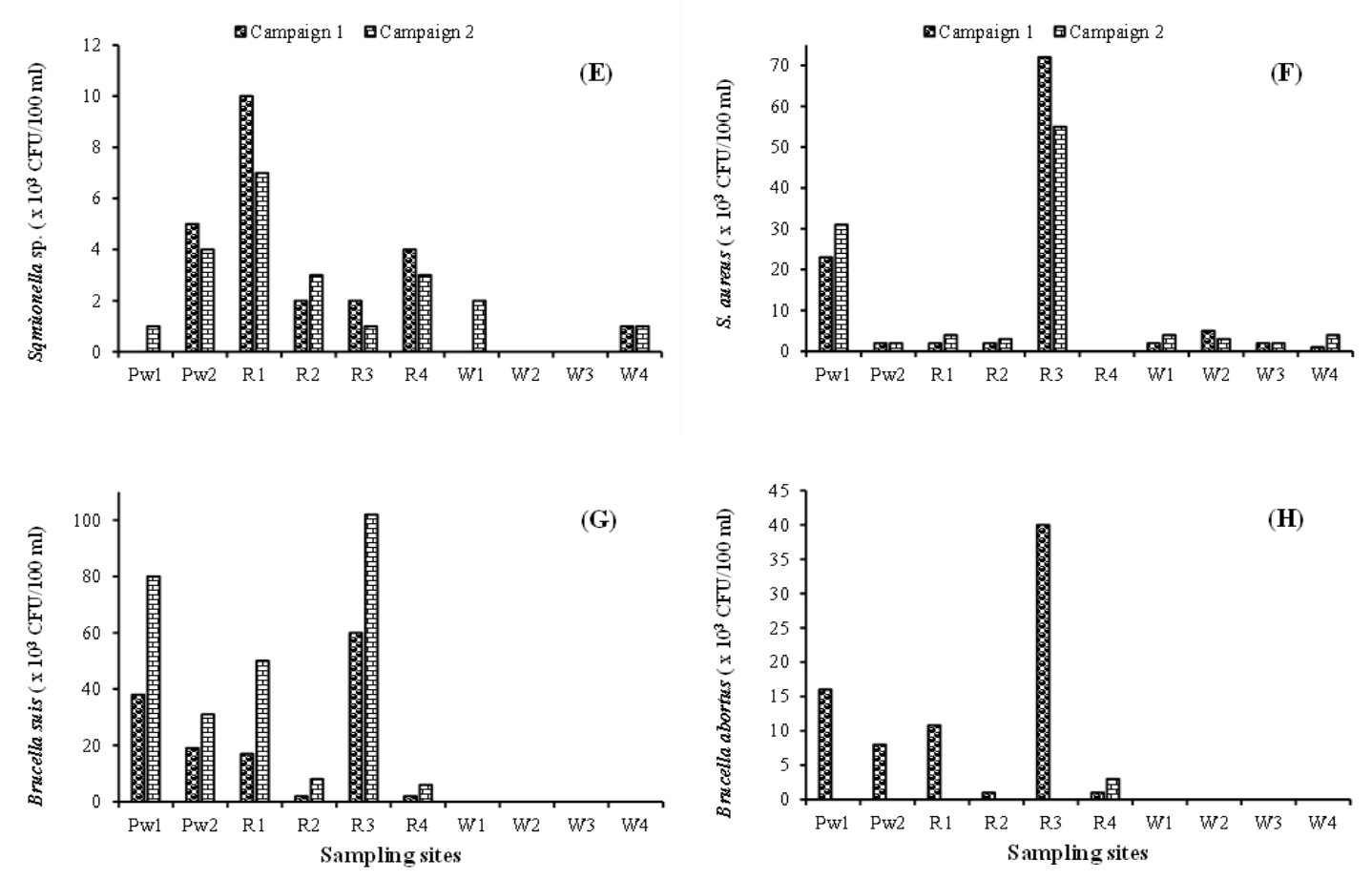

Figure 3 Variation in Salmonella sp. (E), Staphylococcus aureus (S. aureus) (F), Brucella suis (G) and Brucella abortus $(\mathrm{H})$ at the stations studied during the two campaigns (campaign 1 and campaign 2).

Brucella sp. are facultative intracellular bacteria that can survive for more than two months in water at $20^{\circ} \mathrm{C}$ and replicate [12]. Indeed, as highlighted by studies on Escherichia coli, adaptation to a new environment depends on the fraction of metabolically active cells present when the bacteria are exposed to adverse conditions, as well as on the bacterial load [31]. Indeed, evolution is a fundamental multifactorial concept that has shaped the Brucella sp. genome 
over thousands and millions of years. The time scale of adaptation to a host/ecosystem includes on the one hand rapid changes (regulatory systems, DNA repair systems, systems of resistance to extreme environmental conditions), and on the other hand complex processes of evolution and speciation [32]. Therefore, understanding the mechanisms of adaptation, i.e. the ability of bacteria to undergo modifications to increase their ability to react to stress, is an important first step in the global approach to the question of evolution. Indeed, studies aimed at elucidating the mechanisms of short-term adaptation to environmental change have already been carried out on multi-host bacterial populations of pathogens other than Brucella sp. such as Escherichia coli and S. aureus [31,33,34]. The aim is to define the anatomical adaptive properties of bacterial pathogens that can be described in terms of changes in regulatory processes or adaptive mutations (point mutation or horizontal gene transfer).

Brucella abortus naturally affects cattle, but can also affect other domestic and wild ruminants and B. suis has pigs as a reservoir [35]. Brucellosis in animals manifests itself mainly by causing abortion enzootics, infertility and lesion formation in the lymphatic system and joints [36]. These microorganisms are classified as zoonotic pathogens and can therefore be transmitted to humans [12]. Brucellosis in humans is difficult to assess because of its clinical polymorphism. It is most often confused with infections such as malaria and typhoid fever. It manifests itself in the form of fevers, muscle and joint pain, aches and pains, asthenia, profuse night sweats, sexual and psychological disorders [37]. In pregnant women, brucellosis can be responsible for abortions, premature deliveries and death in utero, particularly during the first trimester of pregnancy [38].

\subsubsection{Relative frequencies of isolated bacteria}

In station $\mathrm{P}_{\mathrm{w}} 1$, HABs largely predominated with a relative frequency of $91 \%$. TCs were the second most abundant group (16\%). The relative frequencies of the other germs were 0\% (FC), 0\% (Salmonella sp.), 1\% (FS), 1\% (S. aureus), 1\% (B. suis) and $0 \%$ (B. abortus) (Figure 4). In station Pw2, HAB dominated with a relative frequency of $88 \%$. TCs were the second most abundant group (10\%). The relative frequencies of the other germs were 1\% (FC), 0\% (Salmonella), $0 \%$ (FS), 0\% (S. aureus), 1\% (B. suis) and 0\% (B. abortus) (Figure 4).

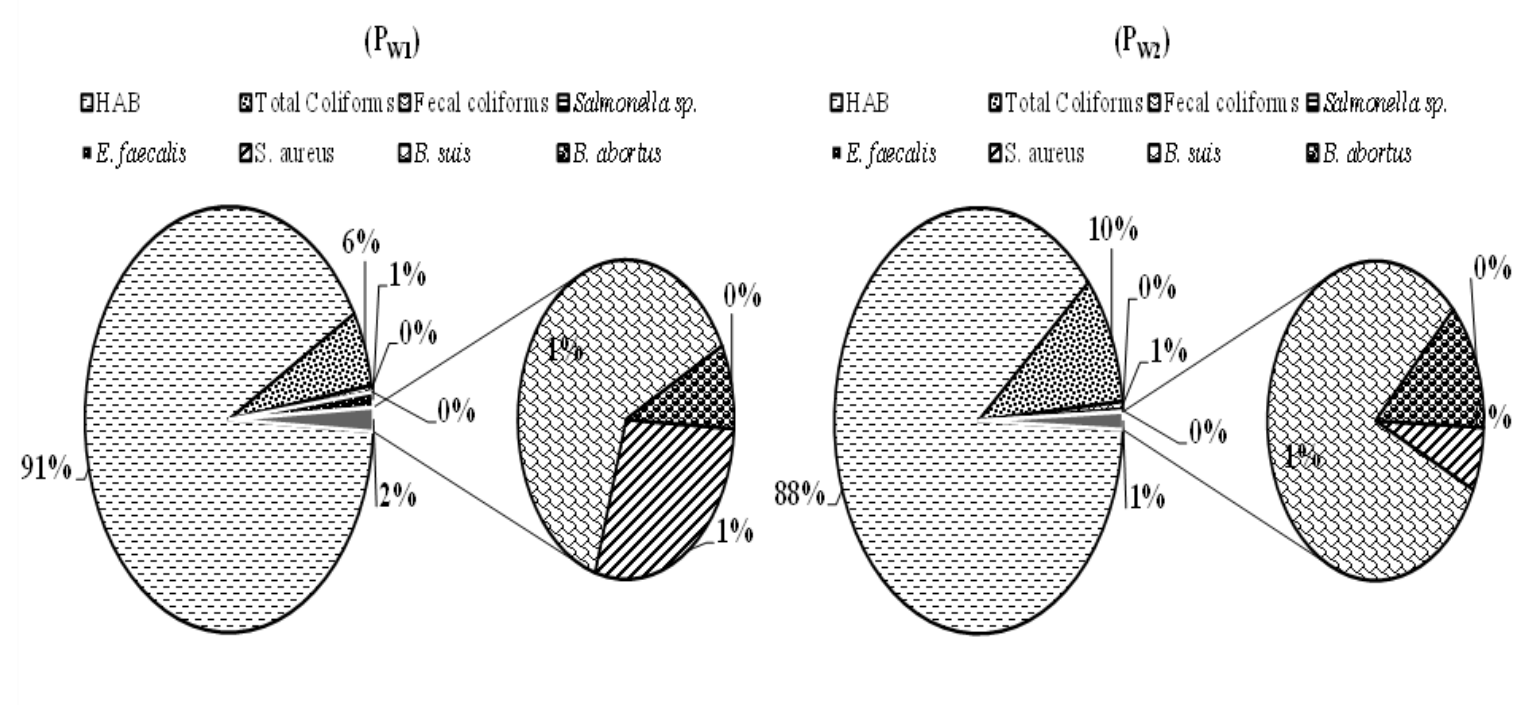

Figure 4 Relative frequency of each group of bacteria studied in the ponds

At the river level, HABs largely predominated with relative frequencies of 65, 64, 95 and $91 \%$ respectively in stations R1, R2, R3 and R4. TCs were the second most abundant group (30,31, 3 and 1\% respectively). The relative frequencies of the other germs were 2, 5, 1 and $0 \%$ respectively for FC, 2, 0,0 and $0 \%$ respectively for $\mathrm{FC}$ and $1,0,1$ and $0 \%$ respectively for B. suis in stations R1, R2, R3 and R4. For Salmonella sp. and B. abortus, their relative frequencies were $0 \%$ for all rivers analyzed (Figure 5 ). 

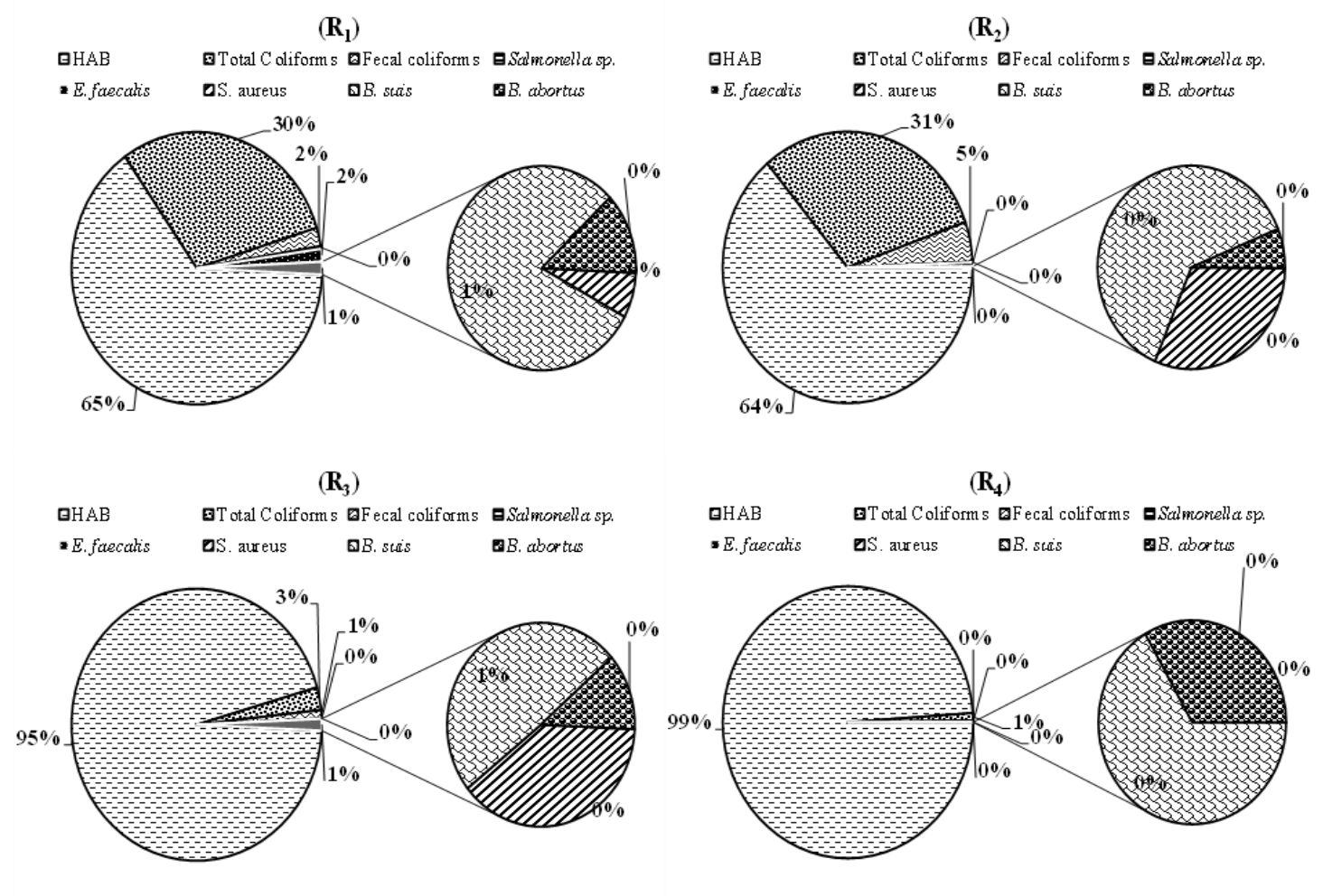

Figure 5 Relative frequency of each group of bacteria studied at the River level

In wells, HABs predominated with relative frequencies of $85,83,87$ and $86 \%$ respectively in stations W1, W2, W3 and W4. TCs were the second most abundant group $(9,13,9$ and $11 \%$ respectively). The relative frequencies of the other germs were 3, 3, 3 and 2\% respectively for FCs, 1, 0, 0 and $0 \%$ respectively for Salmonella sp. and 2, 1, 1 and 1\% respectively for $S$. aureus in stations W1, W2, W3 and W4. For FS, B. suis and B. abortus, their relative frequencies were zero in all wells tested (Figure 6).

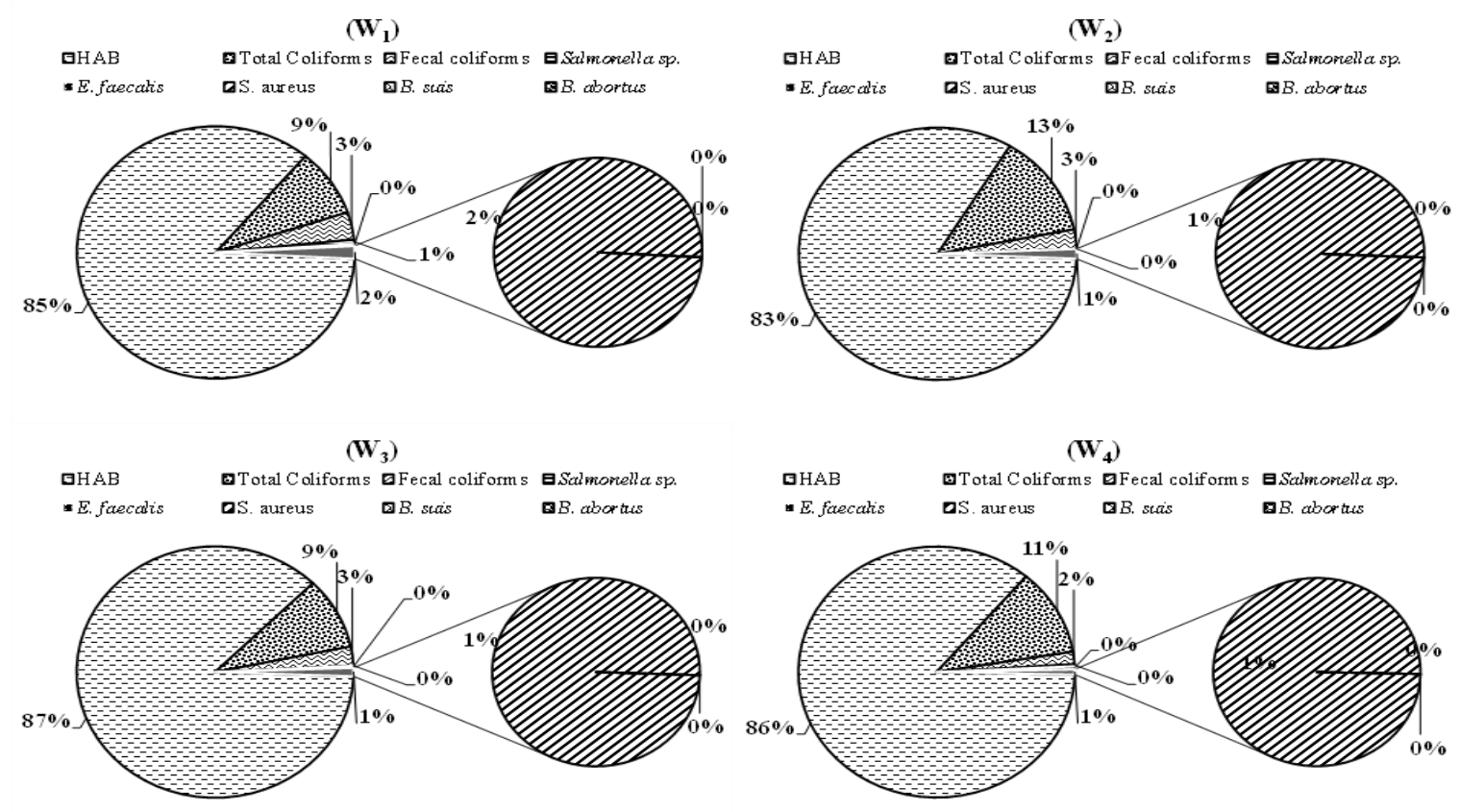

Figure 6 Relative frequency of each group of bacteria studied at river level 
HAB are the groups of bacteria with the highest counts. According to Health Canada [39], the purpose of aerobic bacterial flora enumeration is to estimate the density of the general bacterial population. Salmonella and B. abortus had the lowest relative frequencies in the waters tested. This would be related, as reported by Djaouda et al [5], to nutrient availability and competition with native bacteria.

\subsubsection{Typology of farm waters according to their microbiological characteristics}

The principal component analysis of the bacteriological variables studied during the December and February is presented in figure 7 , showing that the first and second axis explain $43.27 \%$ and $25.47 \%$ of the variance respectively. These two axes account for $68.74 \%$ of the information. The first axis separates the stations according to their degree of contamination (Figure 7B). The second axis is strongly dependent on the indicator variables of hygienic quality of the samples analyzed (TC, FC, Salmonella and E. faecalis) which pull it in the positive direction, as opposed to $S$. aureus, $B$. suis and B. abortus which pulls it in the negative direction (Figure 7A).
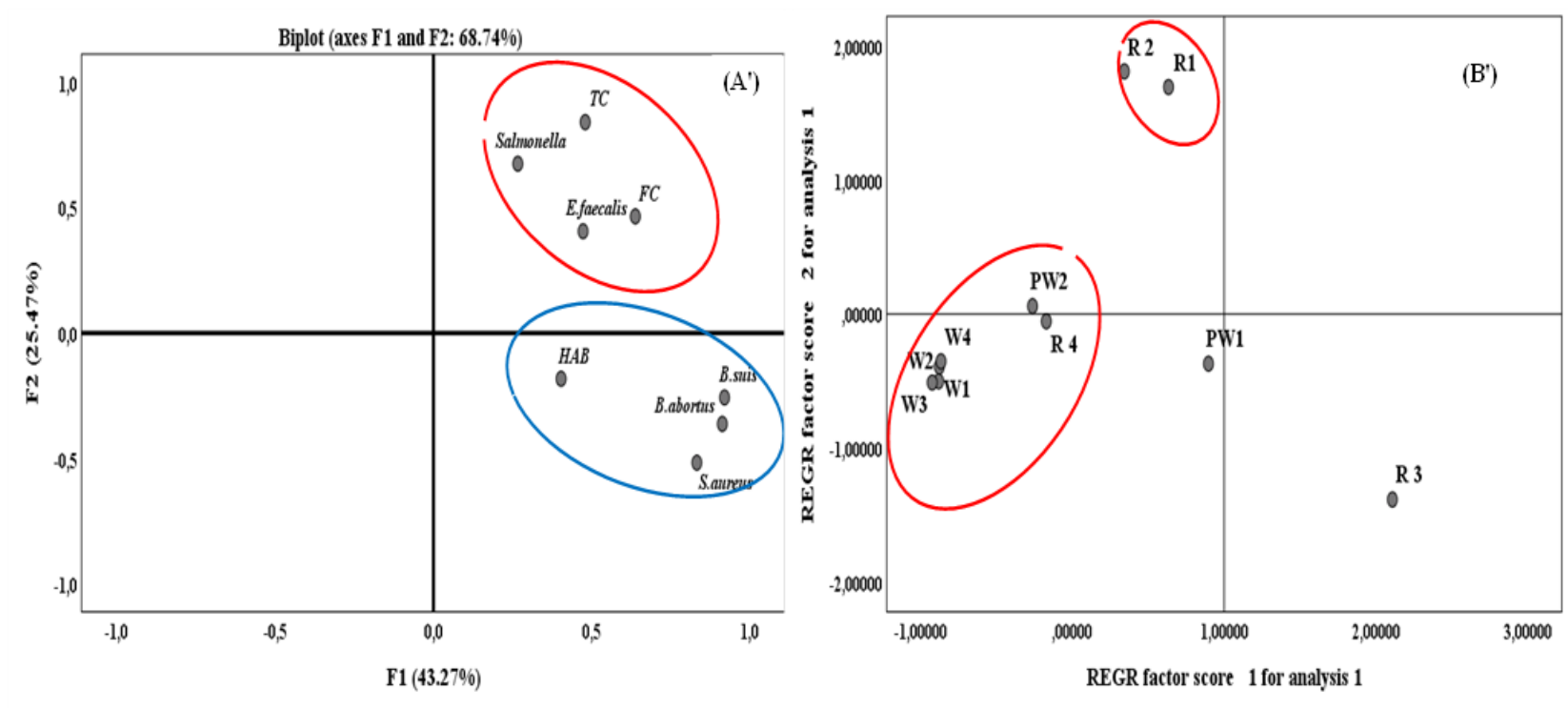

Figure 7 Result of the Principal Component Analysis (PCA) carried out on the physicochemical variables measured in the different stations during the study period: $\left(A^{\prime}\right)$ Biplot showing the distribution of the stations with respect to their physicochemical characteristics in the factorial plane F1 x F2; and (B'): Regrouping of different sampling stations in the factorial plane F1 x F2.

\subsection{Physicochemical parameters}

The measured physicochemical characteristics are shown in figure 8 . The temperature values ranged from 16 to $27^{\circ} \mathrm{C}$. The lowest values were observed at site W1 and the highest at sites PW1 during the two campaigns (Figure 8A). Water temperature is an important factor because it governs almost all physical, chemical and biological reactions. Abrupt changes in this parameter lead to a disturbance in the equilibrium of the water ecosystem [1]. According to Merhabi et al [40], surface water temperature is affected by fluctuations in precipitation and seasonal temperatures. The temperature of an underground environment depends on several factors, the most important of which are latitude and altitude [41]. Temperature affects the density and viscosity of water, the solubility of gases and the level of dissolved oxygen, as well as the speed of chemical reactions.

Dissolved $\mathrm{O}_{2}$ values ranged from 37.5 to $70.6 \%$. The highest values were found at site W3 during both December and February. The lowest values were observed at R1 during the February campaign (Figure 8A). Dissolved oxygen influences the oxidation-reduction potential of water. This potential is decisive for the presence or absence of certain mineral and organic species [42]. Oxygen-depleted waters are highly reducing and may contain in solution ferrous iron, divalent manganese and in some cases even sulfides. 

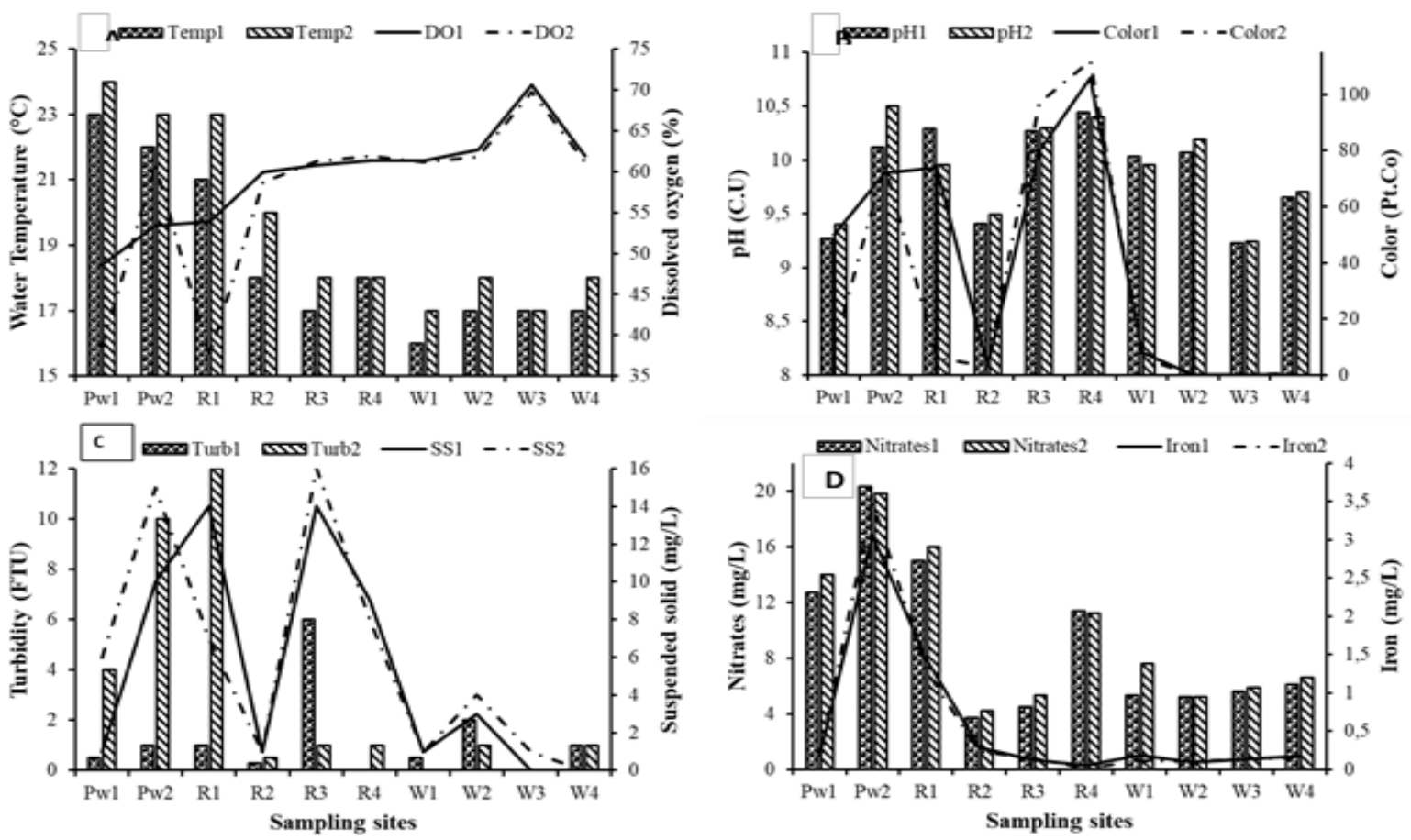

Figure 8 Physicochemical parameters measured during the two field campaigns in December (1) and February Tem: Temperature, DO: Dissolved oxygen, Turb: Turbidity, SS: Suspended solid

The $\mathrm{pH}$ values ranged from 9.23 to $10.5 \mathrm{CU}$ (Figure 8B). The $\mathrm{pH}$ values were basic at all sites. The results obtained are like those reported by Lemoufouet et al [2] in the Sahelian zone of Tchad, where the $\mathrm{pH}$ of ruminant drinking water ranged between 6.18 and $7.22 \mathrm{CU}$. This difference in $\mathrm{pH}$ obtained may be related to the nature of the basaltic soils crossed by the waters in our study area. The $\mathrm{pH}$ of a water depends on its origin and the nature of the soil it flows through [19]. The pH influences most of the chemical and biological mechanisms in water [1].

The water color has oscillated between 0 and 112 Pt.Co. The lowest values were recorded at the wells (W2, W3 and W4), and the highest at site R4 during the two campaigns (Figure 8B). The color results entirely from the extraction of decomposing organic matter, as well as from the dissolution of certain ions such as $\mathrm{Fe}, \mathrm{Mn}$ and $\mathrm{Cu}$ [43]. According to Pelmont [44], these dissolved ions may promote bacterial growth, while others may facilitate the increase in the rate of cell adhesion. Also, color depends on factors such as temperature and $\mathrm{pH}$, which influence the solubility and stability of the dissolved and particulate fractions of water [39].

The water turbidity values ranged from 0 FTU (R4 and W3) to 6 FTU (sites R3) during December and from 0 FTU (W1 and W3) to 12 FTU (site R1) during February (Figure 8C). The SS concentrations ranged from 0 to $14 \mathrm{mg} / \mathrm{L}$ in December and from 0 to $16 \mathrm{mg} / \mathrm{L}$ in February (Figure 8C). Sites W3 and W4 had the lowest SS levels and sites R1 and R3 the highest. Turbidity measurement allows the visual information on the water to be clarified. It indicates the presence of particles suspended in the water (organic debris, clays, microscopic organisms...). However, high turbidity can allow microorganisms to attach themselves to particles in suspension. Turbidity is inversely proportional to water transparency [45]. The SS includes organic and mineral particles transported in the water column. They represent the insoluble matter suspended in water. These particles are torn off by erosion due to rainwater [46]. Their abundance in water favors the reduction of luminosity and lowers biological production, which leads to a fall in dissolved oxygen and slows down photosynthetic activity [47], i.e. self-purification. According to Nisbert and Vernaux [48], SS are involved in the chemical and microbial composition of water through their ion exchange or adsorption effects and can also serve as a substrate for the growth of harmful organisms.

Nitrate values ranged from $3.7 \mathrm{mg} / \mathrm{L}$ (R2) to $20.3 \mathrm{mg} / \mathrm{L}$ (Pw2) during December and from $4.6 \mathrm{mg} / \mathrm{L}$ (R2) to $19.8 \mathrm{mg} / \mathrm{L}$ $\left(\mathrm{P}_{\mathrm{w}} 2\right)$ during February. Nitrates are the dominant nitrogen form in surface and ground water. In the natural environment, its concentration rarely exceeds $0.45 \mathrm{mg} / \mathrm{L}$. Higher values could be due to excessive leaching of organic wastes containing nitrates and the use of fertilizers in nearby agricultural fields [49]. Iron levels in the study sites ranged from $0.01 \mathrm{mg} / \mathrm{L}$ to $3.5 \mathrm{mg} / \mathrm{L}$. The minimum values were recorded at site R4 and the maximum values at site Pw2 during both campaigns (Figure 8D). 
World Journal of Advanced Research and Reviews, 2020, 08(02), 081-094

\subsection{Correlation between the studied parameters}

The Spearman correlation coefficients between the parameters studied have calculated and the values are presented in Table 3.

Table 3 Spearman correlation coefficients between the parameters studied

\begin{tabular}{|l|l|l|l|l|l|l|l|l|}
\hline \multirow{2}{*}{$\begin{array}{l}\text { Abiotic } \\
\text { parameters } \\
\text { considered }\end{array}$} & HAB & TC & FC & FS & Salmonella & S. aureus & B. suis & B. abortus \\
\cline { 2 - 9 } & $0.521^{*}$ & $0.619^{* *}$ & $0.503^{*}$ & 0.370 & $0.508^{*}$ & 0.155 & $0.691^{* *}$ & 0.212 \\
\hline Temperature & $-0.457^{*}$ & $-0.736^{* *}$ & $0.639^{* *}$ & -0.379 & $-0.541^{*}$ & -0.394 & $-0.716^{* *}$ & -0.350 \\
\hline Turbidity & 0.289 & 0.354 & 0.362 & 0.174 & 0.287 & 0.385 & $-0.526^{*}$ & -0.001 \\
\hline Color & $0.792^{* *}$ & 0.415 & $0.504^{*}$ & 0.311 & $0.571^{* *}$ & -0.021 & $0.686^{* *}$ & $0.580^{* *}$ \\
\hline SS & $0.622^{* *}$ & $0.462^{*}$ & $0.501^{*}$ & 0.027 & $0.559^{*}$ & 0.127 & $0.702^{* *}$ & 0.377 \\
\hline pH & 0.426 & 0.123 & 0.223 & -0.146 & $0.509^{*}$ & -0.164 & 0.262 & 0.254 \\
\hline Nitrates & 0.241 & 0.038 & -0.089 & 0.151 & $0.502^{*}$ & -0.191 & 0.341 & 0.178 \\
\hline Iron & -0.014 & $0.485^{*}$ & 0.296 & -0.095 & 0.426 & 0.009 & 0.423 & 0.044 \\
\hline
\end{tabular}

The results obtained show that changes in abiotic parameters such as temperature, dissolved $\mathrm{O}_{2}$, color and SS can lead to changes in the metabolic functions of the bacteria. These results are like those obtained by Lew et al [50]. These changes are less pronounced for FS, S. aureus and B. abortus and more pronounced in Salmonella sp. and B. suis.

The activity level and physiological responses of individual bacterial cells are influenced by environmental and phylogenetic factors. It is unlikely that cells of different bacterial strains and taxa respond identically to environmental stimuli. There is many coexisting bacterial phylotypes in each bacterioplankton community, so there must be many metabolic and physiological responses to any combination of environmental factors, such as $\mathrm{pH}$, temperature, supply rate, and the nature of organic substrates and nutrients [50]. On the other hand, the physiological structure of bacterioplankton is regulated by factors that influence the activity that is intentionally lost, because cells of a higher metabolic level are consumed by protists and infected by viruses [51]. Therefore, the contribution of these cells depends not only on cell division and activity rate, but also on the environment and the number of losses [52].

\section{Conclusion}

Surface and groundwaters from farms in the mountainous region of western Cameroon are alkaline and moderately oxygenated. Some are sometimes colorful and slightly turbid. The nitrate contents are sometimes higher than the norm. These waters host a diverse microflora including among others fecal coliforms, faecal streptococci, and species of the genus Salmonella, Staphylococcus, and Brucella. The nature and extent of relationships between bacterial groups or species and water abiotic factors depends on the considered parameters. The increase in temperature, color and SS has favored the growth of Salmonella $s p$. and B. suis. On the other hand, the high dissolved $\mathrm{O}_{2}$ content has considerably reduced the density of these bacteria. However, the variation in the physicochemical parameters of the medium did not have a significant effect on the bacteria $S$. aureus and B. abortus. More studies on a longer period would lead to monitor this farm water microbiological pollution and its impact on animal health. 


\section{Compliance with ethical standards}

\section{Acknowledgments}

The authors thank the Laboratory of Hydrobiology and Environment of the University of Yaoundé 1 and the Institute of Agricultural Research for Development (IRAD) of Cameroon.

\section{Disclosure of conflict of interest}

The authors declare that there is no conflict of interest regarding the publication of this document.

\section{References}

[1] Balloy Mwanza P, Katond JP and Hanocq P. (2019). Evaluation de la qualité physico-chimique et bactériologique des eaux de puits dans le quartier spontané de Luwowoshi (RD Congo). Tropicultura, 37 (2),2295-8010.

[2] Lemoufouet J, Tendonkeng F, Mekuiko Watsop H, Djimsanodji A, Miegoue E and Mube Kuitche H. (2020). Caractéristiques physico-chimiques de l'eau d'abreuvement des ruminants dans la zone sahélienne du Tchad : cas de Batha Ouest. Afrique SCIENCE, 16(5),44-54.

[3] Nola M, Njiné T, Djuikom E and Sikati Foko V. (2002). Faecal coliforms and faecal streptococci community in the underground water in an equatorial area in Cameroon (Central Africa): The importance of some environmental chemical factors. Water Res., 36:3289-3297.

[4] Bernier-Lachance J, Usongo V, Labrie J, Parent É, Arsenault J, Jacques M, Malouin F, and Archambault M. (2015). Prevalence and antibiotic resistance of livestock associated methicillin-resistant Staphylococcus aureus (LAMRSA) from chicken meat and poultry from the Province of Quebec, 4th ASM Conference on Antimicrobial Resistance in Zoonotic Bacteria and Foodborne Pathogens, Washington D.C., United States.

[5] Djaouda M, Gake B, Zebaze Togouet SH, Wadoube Z, Nola M and Njiné T. (2018). Évaluation de la contamination par Salmonella sp. et Vibrio cholerae des eaux de puits de Garoua, Nord Cameroun. Afrique SCIENCE, 14(4), 209224.

[6] WHO World Health Organization. http://www.who.int/mediacentre/factsheets/fs139/en/.

(2017). Salmonella (non-typhoidal).

[7] Bodering A, Ndoutamia G, Ngandolo BN, Mopate LY and Ngakou A. (2018). Caractéristiques des élevages avicoles et évaluation de leur niveau de contamination par Salmonella sp. et Escherichia coli dans les villes de N'Djamena et Doba au Tchad. Rev. Sci. Tech. Off. Int. Epiz., 37 (3).

[8] OIE. (2016). Brucellosis (infections with B. abortus, B. melitensis and B. suis). Chapter 2.1.4', in Manual of diagnostic tests and vaccines for terrestrial animals, World Health Organization, Paris, viewed May 2016, from https://www.oie.int.

[9] Wallach JC, Giambartolomei GH, Baldi PC and Fossati CA. (2004). Human infection with M-Strain of Brucella canis. Emerg. Inf. Dis., 10(1), 6-8.

[10] Godfroid J, Cloeckaert A and Liautard JP. (2005). From the discovery of the Malta fever's agent to the discovery of a marine mammal reservoir, brucellosis has continuously been a re- emerging zoonosis. Vet. Research., 36, (3), 13-26.

[11] Amona I, Miassangoumouka JP, Banga-Mboko H, Adzona PP, Rabeson FA and Ikolakoumou J. (2016). Dépistage sérologique de la brucellose bovine par l'épreuve a l'antigène tamponné (EAT) et l'ELISA dans un centre de multiplication et de métayage bovin en république du Congo-Brazzaville. Journal of Animal and Plant Sciences, 27 (3), 4315-4329.

[12] AFSSA. (2006). Fiche de description de danger transmissible par les aliments: Brucella sp. Agence Française de Sécurité Sanitaire des Aliments, Fougères, France, 1-4.

[13] Anses. (2010). États des lieux des pratiques et recommandations relatives à la qualité sanitaire de l'eau d'abreuvement des animaux d'élevage. Agence Nationale de sécurité sanitaire de l'alimentation, 121.

[14] Awah-Ndukum J, Mouiche MM, Bayang HN, Ngu-Ngwa V, Assana E, Feussom KJ, Manchang TK and Zoli PA. (2018). Seroprevalence and associated risk factors of brucellosis among indigenous cattle in the Adamawa and north regions of Cameroon. Vet. Med. Int., (Article ID 3468596), 10. 
[15] Awah-Ndukum J, Mouiche MM, Kouonmo-Ngnoyum L, Bayang HN, Manchang TK, Poueme RS, Kouamo J, NguNgwa V, Assana E, Feussom KJ and Zoli AP. (2018). Seroprevalence and risk factors of brucellosis among slaughtered indigenous cattle, abattoir personnel and pregnant women in Ngaoundéré, Cameroon. BMC Infectious Diseases, 18, 11-13.

[16] BCREPC Bureau Central des Recensements et des Etudes de Population du Cameroun. (2010). Rapport de présentation des résultats définitifs » [archive], sur www.statistics-cameroon.org. (Consulté le 06 juin 2016), 810.

[17] PNDP. (2016). Programme National de Développement Participatif : plan communal de développement de Bangangté, 319.

[18] Rodier J. (2009). L’analyse de l'eau, 9e édition », Ed. Dunod, Paris, 1384.

[19] Rodier J, Legube B, Merlet N and Brunet R. (2009). L'analyse de l'eau. Eaux naturelles, eaux résiduaires, eau de mer, 9e éd. Technique et ingénierie, Dunod, Paris, 1600.

[20] Holt JG, Krieg NR, Sneath PHA, Staley JT and Williams ST. (2000). Bergey's Manual of determinative bacteriology. 9th edition. Lippincott Williams and Wilkins (Ed.), Philadelphia, 787.

[21] Diagnostic Pasteur. (1987). Milieux et réactifs de laboratoire Pasteur. Microbiologie et immunologie, 3e éd., Diagnostics Pasteur, Paris, 21.

[22] Scholz HC, Banai M, Cloeckaert A, Kämpfer P and Whatmore AM. (2018). Brucella sp. Bergey's Manual of Systematics of Archaea and Bacteria, 1-38.

[23] APHA (American Public Health Association).(2012). Standard Methods for the Examination of Water and Wastewater, 22th edition ", Ed. American Public Health Association/American Water Works Association/Water Environment Federation, Washington, DC.

[24] Belghiti ML, Chahlaoui A, Bengoumi D and El Moustaine R. (2013). Etude de la qualité physico-chimique et bactériologique des eaux souterraines de la nappe plio-quaternaire dans la région de Meknès (Maroc). Larhyss J., 14, 21-36.

[25] Haseena M and Malik MF. (2017). Water pollution and human health. Environ Risk Assess Remediat., 1(3), 1619.

[26] EPA. (2012). Recreational Water Quality Criteria. U. S. Environmental Protection Agency, 1-69.

[27] Biruhtesfa A, Degmawi P, Mesele A, Genene T, Dereje H, Surafel K and Kebede A. (2017). Occurrence of Escherichia coli 0157:H7 in cattle feces and contamination of carcass and various contact surfaces in abattoir and butcher shops of Hawassa, Ethiopia. BMC Microbiol., 17, 24.

[28] OMS. (1994). Directives de qualité pour les eaux de boisson; Volume 1- Recommandation. Organisation mondiale de la santé, 2e édition.

[29] Jajere SM. (2019). A review of Salmonella enterica with particular focus on the pathogenicity and virulence factors, host specificity and antimicrobial resistance including multidrug resistance. Veterinary World, 12(4), 504-521.

[30] Song J, Lays C, Vandenesch F, Benito Y, Bes M, Chu Y, Lina G, Romby P, Geissmann T and Boisset S. (2012). The expression of small regulatory RNAs in clinical samples reflects the different life styles of Staphylococcus aureus in colonization vs. infection. PLoS One, 7, e37294.

[31] Kim HJ, Jeong H, Hwang S, Lee M-S, Lee Y-J, Lee D-W and Lee SJ. (2014). Shortterm differential adaptation to anaerobic stress via genomic mutations by Escherichia coli strains K-12 and B lacking alcohol dehydrogenase. Frontiers in Microbiology, 5, 476.

[32] Ryall B, Eydallin G and Ferenci T. (2012). Culture history and population heterogeneity as determinants of bacterial adaptation: the adaptomics of a single environmental transition. Microbiol. Mol. Biol. Rev., 76(3), 597625.

[33] Weinert LA, Chaudhuri RR, Wang J, Peters SE, Corander J, Jombart T, Baig A, Howell KJ, Vehkala M, Välimäki N, Harris D, Chieu TTB, Van Vinh Chau N, Campbell J, Schultsz C, Parkhill J, Bentley SD, Langford PR, Rycroft AN, Wren BW, Farrar J, Baker S, Hoa NT, Holden MTG, Tucker AW, Maskell DJ, Consortium BRT, Bossé JT, Li Y, Maglennon GA, Matthews D, Cuccui J and Terra V. (2015). Genomic signatures of human and animal disease in the zoonotic pathogen Streptococcus suis. Nature Communications, 6, 6740. 
[34] Zorraquino V, Kim M, Rai N and Tagkopoulos I. (2017). The genetic and transcriptional basis of short and long term adaptation across multiple stresses in Escherichia coli. Mol. Biol. Evol., 34(3), 707-717.

[35] Boukary AR, Saegerman C, Adehossi E, Matthys F, Vias GF, Yenikoye A and Thys E. (2014). La brucellose en Afrique Subsaharienne. Ann. Méd. Vét., (158), 39-56.

[36] Garin-Bastuji B. (2003). La brucellose ovine et caprine. Le Point Vétérinaire, 34 (225), 22-6.

[37] Rubach MP, Halliday JEB, Cleaveland S and Crump JA. (2013). Brucellosis in low-income and middle-income countries. Curr. Opin. Infect. Dis., 26(5), 404-12.

[38] Duval C. (2014). Connaissances actualisées des maladies rares zoonotiques chez la femme enceinte. Thèse d'exercice, Médecine vétérinaire, Ecole Nationale Vétérinaire, 145.

[39] Santé Canada. (2010). Recommandations au sujet de la qualité des eaux utilisées à des fins récréatives au Canada. 43.

[40] Merhabi F, Amine H and Halwani J. (2019). Evaluation de la qualité des eaux de surface de la rivière Kadicha. Journal Scientifique Libanais, 20(1), 10-34.

[41] Camacho AI. (1992). The natural history of Biospeleology. Nac. Cien Nat \& C.S.I.C., Monografias, 7, 680.

[42] Montiel A. (2007). Qualité de l'eau en élevage avicole, Septièmes Journées de la Recherche Avicole, Tours, 28 et 29 mars 2007, 455-463.

[43] Olanezuk-Neyman K and Bray R. (2000). The role of physic-chemical and biological processes in manganese and ammonia nitrogen removal from groundwater. Polish Journal of Environmental Studies, 9, 91-96.

[44] Pelmont J. (1993). Bactéries et environnement : Adaptations physiologiques. Presses Universitaires de Grenoble, 899.

[45] RéFEA. (2003). Réseau Francophone sur l'Eau et l'Assainissement. www.oie.fr/ReFEZ/, mise à jour : 25 juin 2003.

[46] Auby I, Manaud F, Mauder D and Trut G. (1994). Etude de la prolifération des Algues vertes dans le bassin versant d'Arcachon, Ifremer- Cemagre SSA-SABARC. 192.

[47] Cairns JJR, Lanza GR and Parker BC. (1972). Pollution related Structural and functional changes in aquatic communities with emphasis on freshwater algae and protozoa. Académie Nationale des Sciences de Philadelphie, $124,79-127$.

[48] Nisbert M and Verneaux J. (1970). Composantes chimiques des eaux courantes. Discussion et proposition des classes en tant que bases d'interprétation des analyses chimiques. Annales de Limnologie, 6,161-190.

[49] Gonfa D, Fassil A and Mulissa J. (2019). Assessment of bacteriological and physicochemical quality of drinking water from source to household tap connection in Nekemte, Oromia, Ethiopia Journal of Environmental and Public Health Volume, Article ID 2129792, 7.

[50] Lew S, Glińska-Lewczuk K and Lew M. (2019). The effects of environmental parameters on the microbial activity in peat-bog lakes. PLoS ONE 14 (10), e0224441.

[51] Nola M, Djarmaila E, Kemka N, Chihib NE, Zébazé Togouet SH, Krier F, Servais P, Hornez JP and Njiné T. (2010). Assessment of the future of heterotrophic aerobe bacteria and electrical conductivity in groundwater samples stored in household conditions at different temperatures, in the equatorial region of Central Africa. Afr. J. Microbiol. Res., 4 (20), 2055-2066.

[52] Lew S, Lew M, Mieszczyński T and Szarek J. (2010). Selected Fluorescent Techniques for Identification of the Physiological State of Individual Water and Soil Bacterial Cells-review. Folia Microbiol., 55, 107-118. 